\title{
A NEW HESPERID FROM HAITI (LEPIDOPTERA; RHOPALOCERA)
}

\author{
By E. L. BeLL \\ Flushing, New York
}

Poanes batesi new species

Male. Upper side. Primaries with a conspicuous, oblique, narrow greyish stigma of two parts broadly bordered with black on each side, the upper part, slightly curved, extends from near the base of vein 3 to vein 2 ; the lower part is continued obliquely inward from vein 2 to about the basal third of vein 1 . The costal margin to near the end of the cell and the cell itself are orange fulvous. Basal area of cell 1 orange fulvous, somewhat darker. Outer half of wing blackish brown, well sprinkled with orange fulvous scales. Three subapical orange fulvous spots in interspaces 6,7 and 8. A triangular, semi-hyaline, pale orange fulvous spot in the base of interspace 3 ; a larger, irregular semi-hyaline spot of similar color lies outside the upper part of the stigma in interspace 2 ; in interspace 1 a prominent, though not sharply defined, narrow orange fulvous streak extends along vein 1 from the base of the stigma to under the semi-hyaline spot in interspace 2. Below vein 1 the inner margin is orange fulvous from the base nearly to the inner angle of the wing. Fringes blackish at the base, paler brown at the tip, except at the inner angle where they are orange fulvous.

Secondaries. Costal area above vein 7, abdominal fold and a narrow outer border are black, the rest of the wing orange fulvous, through which some of the black veins feebly show, at the end and along the lower edge of the cell more distinctly than the rest. Fringes orange fulvous with blackish scales at the base and which intermix with the orange fulvous at about the center of the wing border.

Under side. Primaries with the basal area, except at the costal margin, black, at the costal margin the base is bright 
green. A narrow black streak corresponds to the upper part of the stigma, and the end of the cell is narrowly black. The costal margin from the bright green base to beyond the end of the cell, the cell itself, an area enclosing the two semi-hyaline spots of the upper side, are orange fulvous, from here a broad, irregular brown band extends to the margin of the wing. The entire apical area is heavily overscaled with bright green, through which the three sub-

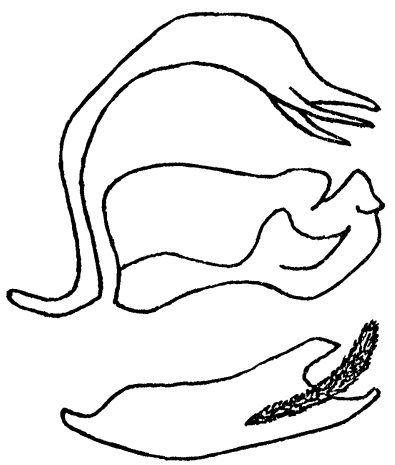

FIg. 1. Poanes batesi new species, male genitalia.

apical spots sometimes indistinctly show. The two semihyaline spots of the upper side are repeated but as they lie in an orange fulvous area they are less distinct than on the upper side. The streak in interspace 1 is larger than on the upper side and much paler in color. Below vein 1 the wing is brown. Fringes at the inner angle orange fulvous, above there brown to the apex, with whitish scales sparsely intermixed at the base, forming a basal line, which varies in distinctness with individuals, and may be entirely lost in very worn specimens.

Secondaries. The ground color is dark brown, heavily overscaled with bright green, except the abdominal fold which remains brown bordered on each side with orange fulvous scales. The green overscaling does not quite reach the outer margin of the wing and thus leaves a narrow marginal line of the dark brown ground color. A discal band of black spots, usually three, as follows: one, squarish or roundish, between veins 2 and 3 , a small one above it be- 
tween veins 3 and 4 , and another small one between veins 6 and 7, which is sometimes absent, and in occasional individuals there is a fourth spot between veins 7 and 8 . Fringes orange fulvous at the anal angle, above there brown at the base and orange fulvous at the tip; the white basal line more distinct than on the primaries.

Body above: thorax blackish; abdomen heavily haired with fulvous and greenish in the basal half, tip of anal tuft orange fulvous. Tegulæ and shoulder covers green. Head and collar green, sometimes with orange fulvous hairs intermixed. Eyes black. Antennæ black.

Body beneath: thorax and abdomen green and orange fulvous. Palpi and pectus green and orange fulvous. Antennæ spotted with yellowish between the joints, the club orange fulvous, apiculus reddish. Legs brownish with fulvous hairs.

Female. Upperside. Primaries dark brown, the basal area and below vein 1 overscaled with dark orange fulvous, the rest of the wing, except the end of the cell, more or less sprinkled with scales of the same color. A narrow orange fulvous streak near the base of the cell on the lower edge and sometimes another, less distinct, above it; both of these in some individuals are either absent or very indistinct. Two semi-hyaline spots in the apical third of the cell, one above the other and sometimes coalescent. Three semihyaline subapical spots in an oblique line in interspaces 6,7 and 8 , sometimes the middle one is a little inward of the other two. A semi-hyaline spot in each of interspaces 2 and 3 and an orange fulvous streak in interspace 1 similar to those of the male. All of the semi-hyaline spots mentioned above are tinted with pale orange fulvous. Fringes orange fulvous at the inner angle, above dark brown and orange fulvous intermixed.

Secondaries. Similar to those of the male but a little darker in tone.

Beneath. Primaries dark brown, except the costal margin which is green at the base and orange fulvous from there to the end of the cell and an orange fulvous spot in the end of the cell in which lies the two semi-hyaline spots of the upper side. The apical area is heavily overscaled 
with green, the three subapical spots edged with white. The semi-hyaline spots in interspaces 2 and 3 are repeated and the streak in interspace 1 is much larger and paler than on the upper side. Fringes orange fulvous at the inner angle, above brown with orange fulvous tips, the white basal line often more distinct than in the male.

Secondaries. Similar in color to the male but instead of the discal band of black spots in that sex there is an irregular discal band of five silvery white spots, bordered outwardly with the dark brown ground color. The band of spots is composed of two sections, the lower part of three spots as follows: one below vein 2, one between veins 2 and 3 and one between veins 3 and 4 , these are in a slightly curved line and the middle one is usually the larger. The upper section of the band consists of two spots, one between veins 6 and 7 and the other, usually the smaller, between veins 7 and 8 . Fringes orange fulvous at the anal angle, above there brown, orange fulvous at the tip. The white basal line is very prominent.

The body and all appendages are similar in color to those of the male.

Expanse: male $32-34 \mathrm{~mm}$.; female $32-36 \mathrm{~mm}$.

Described from 15 males and 6 females collected by D. Marston Bates and P. J. Darlington on the La Selle Range, Haiti, during the latter part of September, 1934, and one female collected by Darlington near Mt. Hotte, Haiti, October 13, 1934.

Holotype male, La Selle Mts., September 23. Allotype female, La Selle Mts., September 20. Paratypes: 14 males, 5 females, La Selle Mts., September 18-23; 1 female, Roche Croix, La Hotte, October 13. The type, allotype, and 16 paratypes are in the collection of the Museum of Comparative Zoology, Cambridge, Mass., M. C. Z. 20141 ; 4 paratypes ( 2 males, 2 females) are in the collection of the author.

It is with pleasure that this beautiful species is named for one of its discoverers, Dr. D. Marston Bates, of the Museum of Comparative Zoology.

The mid tibiæ of batesi are feebly spined and this character together with the linear stigma and genitalic characters of the male seem to best ally this insect with those spe- 
cies contained in the genus Poanes, where it would fall in the group comprising the former genus Paratrytone Dyar which was united with Poanes by Lindsey (University of Iowa Studies, ix, (4), pp. 84, 85, 1921). This section of the genus is represented in the North American fauna by aaroni Skinner and yehl Skinner, and in Mexico by rhexenor Godman, polyclea Godman, aphractoia Dyar and of these batesi is most nearly allied to the last four mentioned but is easily distinguished from them by the characters given in the above description, the green overscaling of the underside of the wings will alone separate it from any of the others. In addition, to date, none of the other species mentioned have been found in Haiti, the habitat of batesi.

Professor Nathan Banks in forwarding the specimens of batesi to the writer supplied the following important and interesting information concerning the region from which they came; he writes that the specimens from the La Selle Mountains were collected on the plateau of that range between 6,000 and 7,400 feet elevation, mostly in open pine woods or along the edge of cloud-forest in the vicinity of the peaks known as Cayes Jacques and La Vesita. The single female taken by Dr. Darlington near Mt. Hotte was found at an elevation of about 5,000 feet and the locality is about one hundred miles from where the other specimens were taken, with much low country between.

Batesi appears to be a species of the high altitudes and in this respect agrees with the Mexican species polyclea Godman and aphractoia Dyar, the type of the first mentioned said to have come from 8,000 feet elevation and that of the second from 13,000 feet elevation. The North American yehl seerns to be a species of the low coastal areas although it does extend into Tennessee, but there are no altitude records available to the writer for that part of its habitat.

The figure of the male genitalia is taken from one of the paratypes from the La Selle Mountains. 

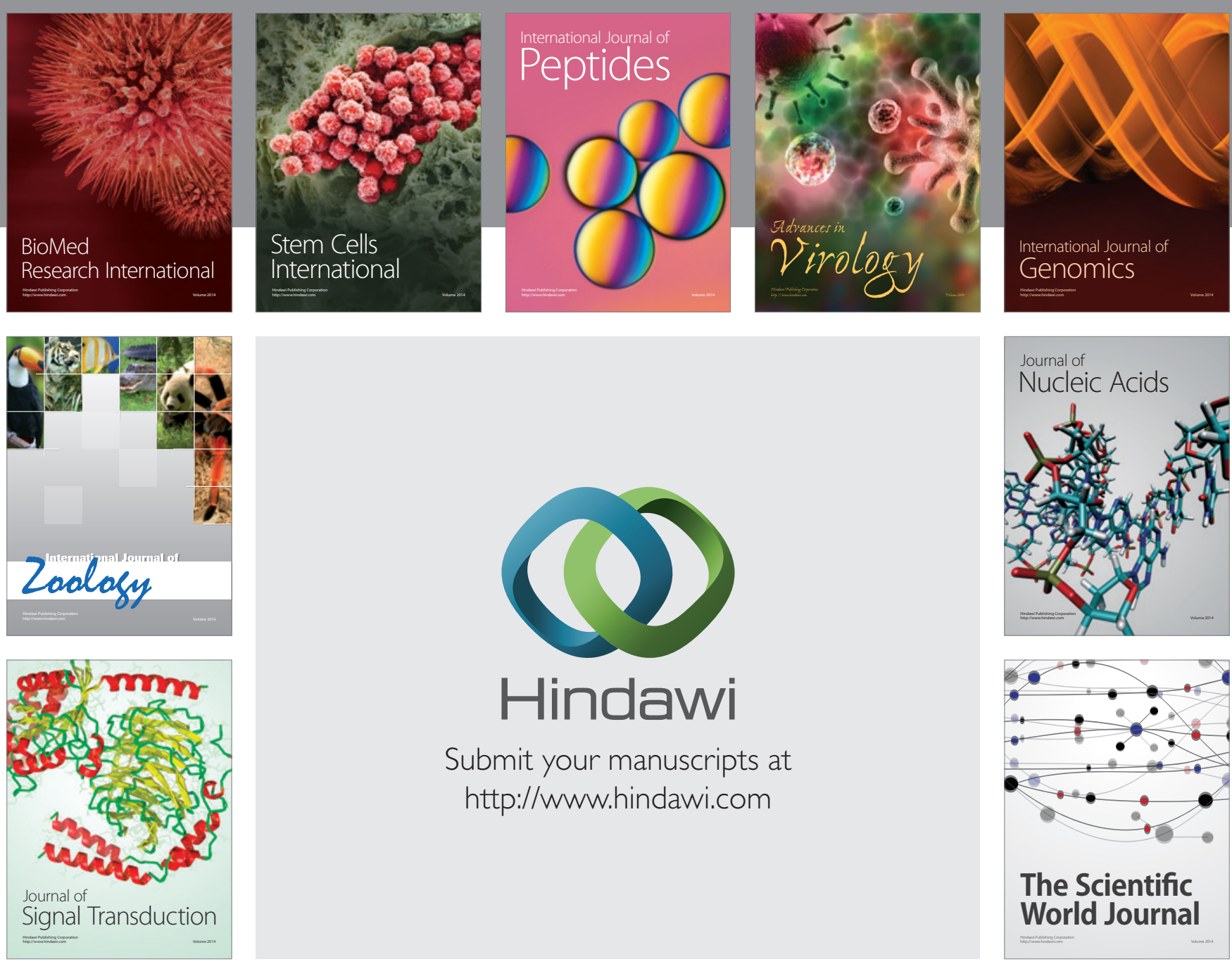

Submit your manuscripts at

http://www.hindawi.com
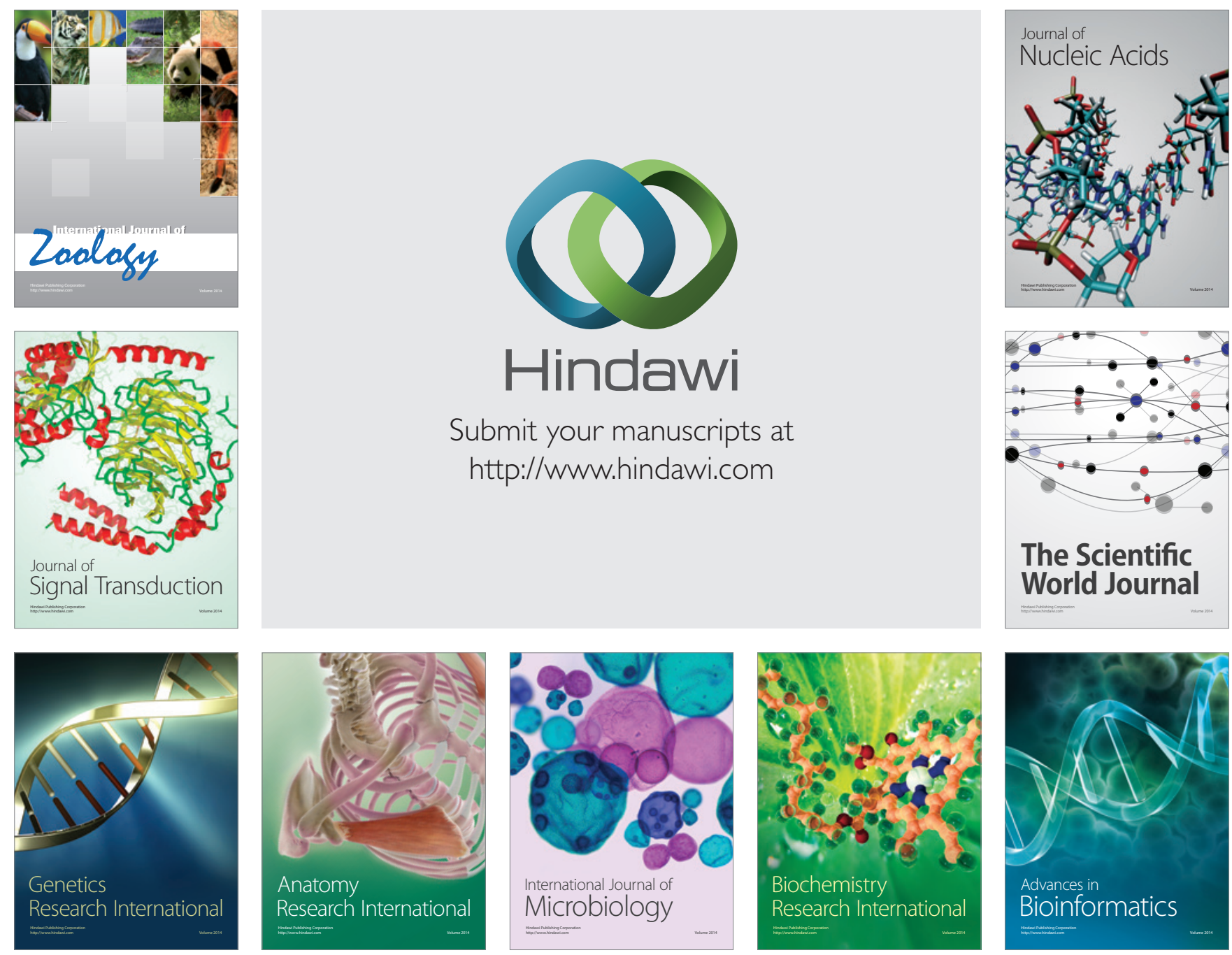

The Scientific World Journal
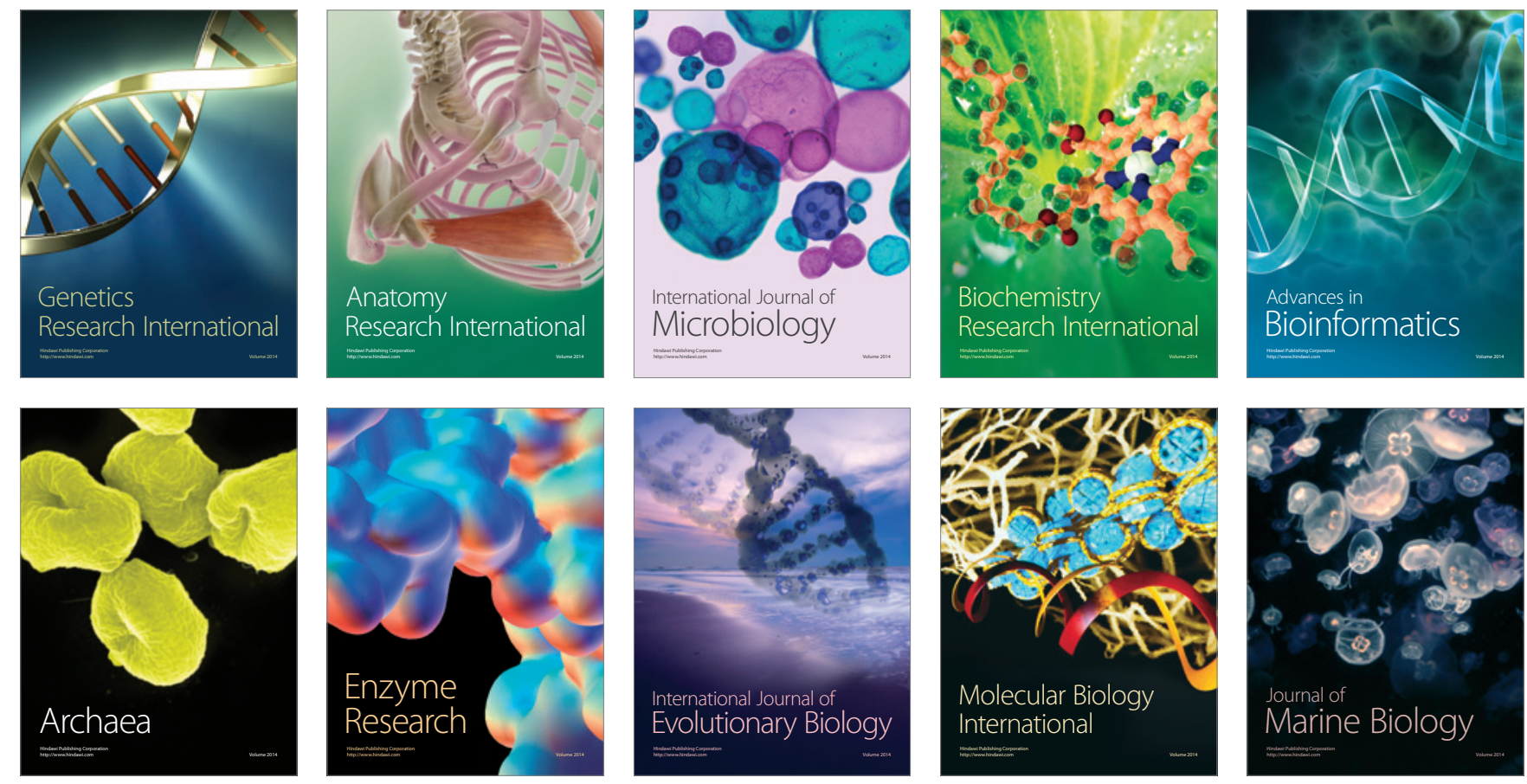